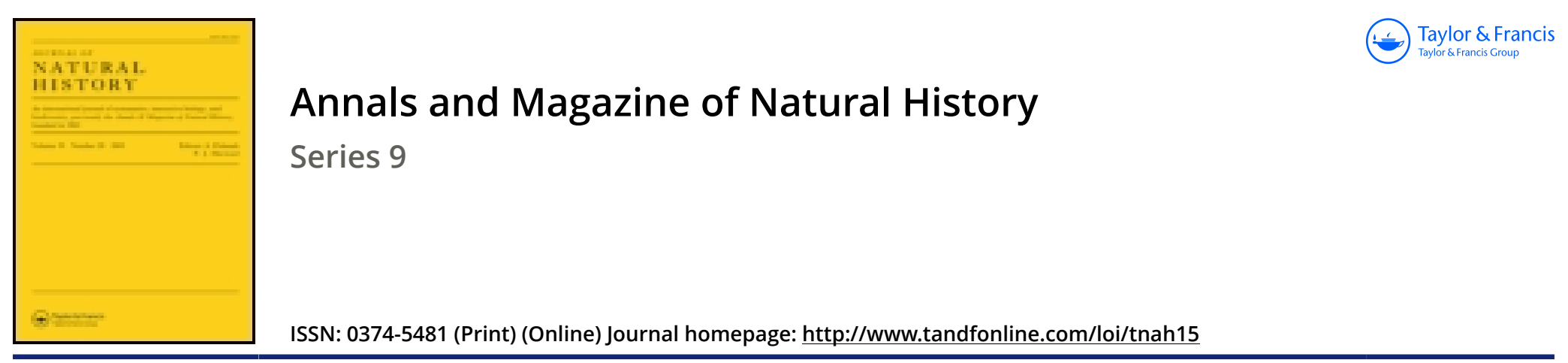

\title{
XXXVI._New Heterocera in the Joicey collection
}

\section{Louis B. Prout F.E.S.}

To cite this article: Louis B. Prout F.E.S. (1918) XXXVI.-New Heterocera in the Joicey collection, Annals and Magazine of Natural History, 1:4, 312-318, DOI: $10.1080 / 00222931808562319$

To link to this article: http://dx.doi.org/10.1080/00222931808562319

册 Published online: 02 Sep 2009.

Submit your article to this journal $\widetilde{ }$

III Article views: 4

Q View related articles $\longleftarrow$ 
traversing the lower surface of the baculum. The edge of the cup on each side of this cleft forms a lobate thickening.

The measurements of the baculum examined, which was extracted from a specimen of Mellivora ratel, are as follows:'Total length in a straight line $70 \mathrm{~mm}$.; length along the inferior curve $77 \mathrm{~mm}$.; width at the base $11 \mathrm{~mm}$., at the narrowest point behind the upcurved end $4 \mathrm{~mm}$.; of the expanded cup-like termination $12 \mathrm{~mm}$, height of the latter $9 \mathrm{nmm}$.

It may be added that in Mellivora, as in other genera and species of Mustelines with the tip of the baculum upcurled, the urethral canal does not follow the curvature, but runs straight forwards, following the line of the lower surface of the baculum.

\section{XXXVI.-New Heterocera in the Joicey Collection. By Louis B. Prout, F.E.S.}

\section{Family Zygænidæ.}

\section{Subfamily $C_{\text {HaLCosIINas. }}$}

\section{Eterusia proprimarginata, sp. n.}

d. $-48 \mathrm{~mm}$.

Head and body above black, beneath pale buff; collar red, as in pulchella, Koll. Abdomen above with very fine, in part interrupted, buff rings at the extremities of the segments.

Wings shaped as in pulchella. Fore wing brownish black, the yellow markings consisting of a longitudinal streak behind cell from base, as in pulchella, the transverse median band more interrupted at $M$ than in that species; a large spot at the discocellulars, and a row of submarginal spots between $\mathrm{SC}^{5}$ and $\mathrm{M}^{1}$, recalling the anterior part of the series which is developed in elizabetha, Walk. Hind winy predominantly yellow, blackened in proximal part of cell, on veins $M$ (as far as the origin of $M^{1}$ ), $M^{2}$, and $S M^{3}$, in the abdominal region to the same extent as in elizabetha, and irregularly at the distal margin, the border being rather narrow (about $2 \mathrm{~mm}$.) between apex and $\mathrm{M}^{1}$, then forming a triangular proximal projection; a roundish black spot between $R^{3}$ and $M^{1}$, nearly touching the distal border. 
Fore wing beneath with the ycllow markings a little broadened, the subapical ones palcr. Hind wing beneath with the black parts only feebly expressed (olive-grey), but with two strong roundish black outer spots, one corresponding to that of upperside, the second between $\mathrm{M}^{2}$ and $\mathrm{M}^{2}$.

Chang Yang, Central China, July 1888 (A. E. Pratt). Type in Coll. Joicey ; $2 \delta$ o in coll. Brit. Mus. Also a o from Ichang and one from Ta-tsien-lu in coll. Brit. Mus.

Unaccountably mixed by Leech among elizabetha; collar red, wings narrower, fore wing wanting the yellow longitudinal line in cell and the large submarginal spot behind $\mathrm{M}^{2}$; hind wing wanting the black trausverse marli near end of cell and with narrower, quite differently shaped distal border. Evideutly nearer to pulchella, but larger, both wings differently marked in distal half.

Family Geometridæ.

\section{Subfamily HEMITHEINA.}

\section{Synclysmus nigrocristatus, sp. n.}

\section{o.-31 mm.}

Face whitish, irrorated with light brown and darker redbrown, a small pointed tuft at the lower extremity tipped with the latter colour. Palpus black on upper and outer sides and at tip. Vertex white mixed with brown. Thorax dirty white, much mixed with brown and red-brown above, and in part with black. Abdomen more ochreous, with rather strong brown black-mixed crests; a red tinge on sides.

Fore wing white, shaded with light brown (less strongly in submedian and terminal areas than in the rest of the wing) ; lines formed of black irroration more condensed at anterior end; first extremely oblique from costa at base; antemedian from costa at $3.5 \mathrm{~mm}$. to middle of hind margin, sinuous, excurved in cell, incurved between fold and $\mathrm{SM}^{2}$; postmedian at about two-thirds, dentate, rather deeply inbent between the radials and again between $M^{1}$ and fold; a more reddish-brown shade between this and the very indistinct, dentate, whitish subterminal; termen with elongate black markings between the veins.

Hind wing long (Pingasa-shaped), whiter than fore wing, Ann. \& Mag. N. Hist. Ser. 9. Vol. i. 
with postmedian line indicated posteriorly, marked with a small dark spot at abdominal margin and slight indications of small admarginal spots between the veins; terminal markings as on fore wing. Fore wing beneath white, in anterior part (except towards distal margin) with some coarse dark irroration, at costal margin mixed with reddish ; a slight blackish patch at base of costa, a stronger one at origin of postmedian line, which otherwise is scarcely developed; terminal markings weaker than above. Hind wing beneath with weak terminal markings.

Diego-Suarez, Madagascar.

\section{Heterorachis melanophragma, sp. n.}

万. $-22 \mathrm{~mm}$.

Face blackish brown. Palpus beneath pale. Vertex white. Antenna pale ochreous, in places with a tinge of reddish ; pectinations long. Thorax above green ; abdomen above reddish sprinkled with black, the anterior segments each with a white spot, the posterior ones with a white belt. Underside of body and legs pale; fore leg somewhat marked with red; hind tibia somewhat dilated.

Fore wing with $\mathrm{SC}^{\dagger}$ anastomosing slightly with $\mathrm{C}, \mathrm{R}^{3}$ connate, $\mathrm{M}^{1}$ connate ; pale French-green or dull malachitegreen, more opaque than diaphana, Warr.; costal edge narrowly ochreous; a small black cell-dot; a slender interrupted brown terminal line, strongly sprinkled with black scales; fringe chequered, blackish opposite the veins, white between.

Hind wing with termen more ventricose than in diaphana; $\mathrm{C}$ anastomosing very slightly with $\mathrm{SC}$, continuing appressed for a short distance, $\mathrm{SC}^{2}$ short-stalked, $\mathrm{M}^{1}$ short-stalked; as fore wing. Underside whitish green, unmarked ; costal edge of fore wing rather more broadly ochreous than above, but somewhat paler,

Diego-Suarez, Madagascar.

\section{Subfamily STERRIIINA.}

4. Anisodes (Pisoraca) concinnipicta, sp. n.

o. $-4.1-42 \mathrm{~mm}$.

Face and palpus dull reddish above, whitish buff below; palpus long (nearly three times diameter of eye), second joint 
with the erect hairs of upperside strongly developed, third joint nearly as long as second. Vertex and antennal shaft pale, with only very minute and very sparse pink irroration. Thorax and abdomen concolorous with wings ; tegula with a geranium-pink transverse bar near extremity; abdomen with pink dorsal dots on first two or three segments; hind tibia with the single proximal spur well developed.

Fore wing moderately elongate, termen almost smooth; cream-buff with fine pink irroration; a minute pink whitish-pupilled annulus on DC; antemedian pink dots placed as in fastidiosa, Dogn. (Ann. Soc. Ent. Belg. xliv. p. 441), but ou an average more elongate, especially that on the cell-fold; a faint zigzag grey median shade placed nearly as in fastidiosa or still more oblique posteriorly; postmedian pink dots nearly parallel with median shade, connected by faint traces of a fine line ; submarginal pale line very feebly indicated by faint shades proximally and distally ; terminal dots small, but sharp.

Hind wing with termen subcrenulate, with an appreciably stronger tooth at $\mathrm{R}^{3} ; \mathrm{M}^{1}$ widely separate from $\mathrm{R}^{3}$; markings corresponding to those of fore wing. Underside less irrorated; markings nearly as in fastidiosa, median shade of fore wing rather broad, proximal subterminal shade of fore wing and median shade of hind wing rather well developed.

Sierra del Libane, Colombia, 6000 ft. (H. H. Smith), $2 \delta$ o .

May be placed next to punctulosa, Warr. (Nov. Zool. xi. p. 31).

Subfamily GHOUETRIN.E.

5. Mimaletis paucialbata, sp. $\mathrm{n}$.

o. $-40-43 \mathrm{~mm}$.

Head and boly with the colouring of the rest of the group (postica, Walk., \&e.), the three areas of the face (black down the centre, white down the sides) sharply defined, the white dorsal markings of abdomen not very broad.

Fore wing narrower than in the allies; the orange groundcolour less reddish; costal edge very narrowly black to base; a very small black basal mark, throwing out a slight prong along $\mathbf{M}$; black apical border broad anteriorly, its margin commencing at middle of costa and ruuning fairly straight to hind margin close to tornus, slightly crenulate; 
the contained white spots small, the anterior one not reaching $\mathrm{SC}^{5}$ or $\mathrm{R}^{3}$, the second very small and the third a minute dot; posterior margiu slightly folded and narrowly blackish.

Hind wing slightly narrower than in the allies; the black cell-spot large; border not broad, the white spots small or very small, anteriorly obsolescent. Underside similar, but with the white spots of hind wing slightly better developed.

Lake Bangweolo, N. Rhodesia, Sept. 1917 (T. A. Barns), $2 \delta$ 万.

Superficially nearest to reducta, Prout (Nov. Zool. xxii. p. 369), but with the white spots still further reduced; very distinct in shape, robuster build, coloration, large cell-spot of hind wing, \&c.

\section{Craspedosis niveosignata latesignata, subsp. $\mathrm{n}$.}

8.-Distinguished from name-typical niveosignata, Warr. (Nov. Zool. vi. p. 47, Ron Island), by having the white patches broader (on fore wing at $R^{3} 4 \mathrm{~mm}$., on hind wing from proximal edge to distal edge at $R^{3} 8 \mathrm{~mm}$.), sometimes in addition blurred white scaling behind middle of cell of fore wing. Abdomen with the black belts dorsally interrupted or obsolete.

Mysol, foot-hills, 100-500 ft., Oct.-Nov. 1916, net season (W.J.C. Frost), $3 \delta$ ठे.

\section{Family Hypsidæ.}

\section{Aganais diastropha, sp. n.}

d. $-55 \mathrm{~mm}$.

Head orange; palpus with a black spot at end of first and of second joint, third joint wholly black; antenna black. Thorax and abdomen orange, paler beneath; abdomen with black spots dorsally and laterally.

Fore wing with termen curved, extremely oblique, hind margin slightly excavated close to tornus, then protuberant, the sex-patch strongly developed ; fawn-colour, proximally mixed with orange, without sharp demarcation; the cellspot of underside showing through. Underside orange, rather paler than above, the apical region of fore wing (from costa just before cell-spot to tornus) and the sexpatch and a few apical scales of hind wing fawn-colour with 
a smoky admixture; fore wing with a large black cell-spot, hind wing with a black dot.

Maevatanana, Tananarivo district, Madagascar, 2 os $\delta$.

It is not altogether impossible that this may be the $\delta$ of concolora, Swinh. (Ann. \& Mag. Nat. Hist. (7) xi. p. 503), described from the $q$ only, but it seems very improbable, as that has broad wings, the second joint of palpus more extended black above, the tarsi and spurs black, \&c.

\section{Nyctemera pellex frosti, subsp. n.}

万. $-40-43 \mathrm{~mm}$.

Fore wing with the white spots reduced in size; the elongate white hind-marginal streak reduced to a small spot ( 1 or $2 \mathrm{~mm}$. in length) at 5 or $6 \mathrm{~mm}$. from base.

Hind wing with black border strongly broadened (as in some aberrations of pellex separata, from the Northern Moluccas) ; abdominal margin broadly grey-black, this shade extending at least to the fold, and proximally encroaching so as even to enter the cell; the black at costal margin shaped as in pellex separata.

Kei Islands, Dec. 1916-Feb. 1917 (W. J. C. Frost), type $\delta$ and another.

\section{Nyctemera luctuosum rostrigera, subsp. n.}

9.-Forewing with the white subbasal patch behind the cell enlarged, reaching posteriorly to $\mathrm{SM}^{2}$, thus only separated, in its distal part, from the hind-marginal white streak by a line along $\mathrm{SM}^{2}$; postdiscal white band in general somewhat narrowed; a beak-shaped white projection outward from this band between $R^{2}$ and $R^{3}$, as in galbanum, Swinh.; fringe sometimes whitened towards tornus. Hind wing with the white in the fringes more or less extended.

Philippines: Cebu (J.J.Mounsey), type $q$ and another; Mindanao (ex Semper), two $q$.

This is certainly the luctuosum of Semper (compare Schmett. Philippinen. p. 492, pl. lviii. fig 1), but I am by no means certain that it is not a distinct species or possibly a dimorph of galbanum, Swinh., wanting the characteristic white spot in cell of fore wing; compare the remarks of Semper (l.c.) under that species, though galbanum is certainly not the Luzon representative of luctuosum (rostrigera), for the Joicey collection possesses three typical galbanum from Cebu. 


\section{Family Liparidæ.}

10. Otroeda varunce tenuimargo, subsp. $\mathrm{n}$.

o. Fore wing with the black border much reduced, at its widest part $8 \mathrm{~mm}$., behind $\mathrm{R}^{2}$ scarcely over $1 \mathrm{~mm}$. in width, vanishing in a point before $\mathrm{M}^{2}$; the contained white spots also reduced, well separated, the one between $R^{3}$ and $R^{3}$ placed entirely on the ground-colour, in an angle which is formed by the apical and discal border.

Hind wing with the border rather narrow.

Abercorn, N. Rhodesia, June 1917 (T. A. Barns).

The first eastern representative known to me of this group. Some entomologists to whom I have shown it have thought it a good species, chiefly on account of the angle in the black border of the fore wing ; but as I have seen some rather intermediate aberrations from the Lualaba River, Congo, I feel satisfied it is merely a local race. The black streaks from costa are not extremely attenuated; the proximal ends on $\mathrm{M}^{2}$ about $5 \mathrm{~mm}$. from its origin, the distal in a fine point just behind $\mathrm{M}^{1}$, but both will probably prove more or less variable in development.

XXXVII.-Note on Laccoptera vigintisex-notata, Buheman. By S. Maulik, B.A. Cantab., F.E.S., F.Z.S.

'THE object of this note is to clear up the confusion among the different varieties of Laccoptera mentioned below. Hitherto they have been considered different species, porhaps owing to insufficient material. This note is based on the material contained in the collection of the British Musoum, as well as on that of the Indian Museum and other sources from India. 'The figures show the form of the insect, but they are mainly intended to show the disposition and situation of the black spots on the prothorax and the elytra. The surface-structure of the insect is not represented in the drawings.

Laccoptera vigintisex-notata, Boheman.

Laccoptera 26-notata, Boh. Mon. Cassid. iii. 1855, p. 66.

Var. Laccoptera novemndecimnotata, Boh. Mon. Cassid. iii. 1855, p. 67.

Var. Laccoptera hospita, Boh. Mon. Cassid. iii. 1855, p. 68.

Var. Laccoptera multinotata, Boh. Mon. Cassid. iii. 1855, p. 70. 